\title{
THE POWER METRICS OF THE RUSSIAN FEDERATION TOWARDS THE G7 OVER THE PERIOD 1992-2020
}

\begin{abstract}
This paper deals with the subject of the strength of the key world powers in the years 1992-2020. These include the G7 group and the Russian Federation, which was suspended from the group, and so far has not been authorized to resume meetings with the G7 group. In this period, after Russia's exclusion, both regional and global rivalry grew in the world. This translated into the global imbalance of power and an overall geopolitical situation. In this paper, the author proposes a quantification of the power to measure power metrics. Based on the data from the World Bank and Military Balance, the general (economic), military and geopolitical potential of the Russian Federation, Canada, France, Germany, Italy, Japan, Great Britain and the United States was developed. The model of Mirosław Sułek was applied to calculate the power, which reflects the objective reasons for changes in shaping the potential of the aforementioned countries. The purpose of this article was to determine the changes in the power of the G7 countries and the Russian Federation in the years 1992-2020. This translated into the international balance of power and the struggle for influence in the world.
\end{abstract}

Keywords: Russian Federation, G7, powermetrics, security.

\section{INTRODUCTION}

In the period of the development of the world economy, consumer societies, militarization and threats to the world, and globalization, alliances and unions of states, including informal ones, have played a great role in the 21 st century. With the disappearance of the 19th-century concert of powers and the block system, international organizations began to gain importance in the coming decades. Already the League of Nations, and then the United Nations set new trends in world management and preventing any crisis. From the second half of the 20th century, the potential of countries concentrated in the European Communities, NATO, the European Union, NAFTA and now in the BRICS has been growing. Formal organizations further facilitated the development of their members in terms of trade or the power to influence other state or transnational entities. Also today, the greatest powers seek to gain influence on the politics of other countries through informal alliances and unions. The strength of an organization is measured by the strength of its

\footnotetext{
${ }^{1}$ Krzysztof Surowiec, PhD, Department of Humanities and Social Sciences, Faculty of Management, Ignacy Łukasiewicz Rzeszow University of Technology, ul. Podkarpacka 1, 35-082 Rzeszów; e-mail: ks@prz.edu.pl. ORCID: 0000-0002-6298-2260.
} 
members and how quickly they are able to reach a common position on important issues, especially when they are taken at the highest levels of government. One such an important informal organization that is an intergovernmental political forum is the G-7 Group, consisting of Canada, France, Germany, Italy, Japan, Great Britain and the United States. In addition to the above-mentioned powers of the world economy and military, representatives of the European Communities, and currently the European Union, also participate in the deliberations. Due to the fact that the European Union (Sułek, 2014) is a unique supranational organization - not a sovereign member state - the name "G-7 Group" was adopted. The EU is, therefore, not a named member and is not taking over the rotating presidency of the G7. Its presence at the G-7 summits began as early as 1977, two years after the first summit, held in France in Rambouillet, near Paris. Since the Ottawa Summit in 1981, representatives of the European Community participated in all working sessions. The G7 countries are officially organized around common values, pluralism and democracy in social and political life. The G-7 group, together with the complementary role of the G-20 group, influences the most important political decisions of global importance, although they do not have legal force and are primarily opinion-forming (Matera, 2006). However, they influence states through formal ${ }^{2}$ institutions that are competent to introduce permanent changes in global politics ${ }^{3}$.

Representatives of other nations and international organizations are often invited as guests, with Russia being a formal member (within the Group of Eight, G-8) from 1997 to 2014. The beginning of cooperation with Russia was the summit in Naples in 1994 and Denver in 1997, while next year the new G-8 group was officially named. The co-opting of Russia was to improve world security in terms of disarmament, nuclear weapons control and counter-terrorism. The ongoing political and system transformation in Russia itself and in other countries of the former Soviet bloc was also of great importance. Western countries also wanted to have an impact on this, especially in terms of the possibility of granting loans in exchange for opening their markets and economies to investments by the West, especially in Russia. However, this cooperation ended in 2014, when the Russian Federation was suspended from membership rights ${ }^{4}$ on 24 March. This was related to the illegal annexation of Crimea belonging to Ukraine, which was condemned by the other members (Scazzieri, 2017). As a result, the summit in Sochi, which was planned for June 2014, was cancelled. Again, the G7 countries with the European Union met at the Brussels summit, and since then Russia has not been invited to the G7 summits. On January 13, 2017, Russia announced that it would permanently leave the G8 (Batchelor, 2017).

The purpose of the paper was to identify the power of the key actors/superpowers of the modern world - the Russian Federation and the states gathered in the G-7 Group in 1992-2020. In this period, after Russia's exclusion, both regional and global rivalry grew

2 These include, inter alia, organizations cooperating with the United Nations, coordinated by the Economic and Social Council (ECOSOC).

${ }^{3}$ In particular, it is about: the UN Security Council (UNSC), the International Monetary Fund (IMF), the World Bank (WB), the World Trade Organization (WTO), the Organization for Economic Cooperation and Development (OECD) and many others responsible for political security, economic, military, humanitarian and ecological.

4 On March 20, 2014 in the Bundestag, Chancellor Merkel stated: "As long as there is no political climate for such an important format as the G8, there is no G8, neither as a summit meeting nor as the G8 itself" (PAP). 
in the world. This translated into the global balance of power and the overall geopolitical situation. The COVID-19 pandemic in recent years has also been of great importance.

\section{THE POWER OF THE G7 GROUP AND THE RUSSIAN FEDERATION ACCORDING TO THE SULEK'S MODEL}

The power of states has been the subject of interest of rulers and politicians since time immemorial. The question of why some countries surpass others and win international rivalry also bothers today's researchers. Determining the parameters of the power of states nowadays is a challenge for many governments as part of the strategic studies being developed in order to achieve an increase in the geopolitical position in the future (Larsdotter, 2019). The measurement of power is dealt with in a science called powermetrics. It is the science that deals with the measurement of power, especially of states, it applies qualitative and quantitative methods to the study of international relations (Sukek, 2013). The intensification of research on these issues took place especially after the collapse of the USSR in 1991 and with the end of the bipolar system in the modern world. A special feature of the current international system is its instability. This, in turn, generates attempts to determine the position of a given country in the balance of power and development trends for the future in this regard. Thanks to this research, the role of geopolitics as a science was restored, especially badly treated in Europe subordinated to the Soviet Union after 1945.

The balance of power is the most important feature in international relations. The term was also used by Raymond Aron, according to whom: "The most important feature of any international system is the balance of power" (Aron, 1995). Adam Daniel Rotfeld pointed out that: "the international system is a specific dynamic system of inter-state relations, which protects - in the form of treaties or political agreements - a set of values and interests recognized by its creators, and defines the rules of conduct in their mutual relations and self-regulation mechanisms enabling the maintenance and development of and adapting the system to changing conditions" (Rotfeld, 1990). On the other hand, according to Bertrand Russell, "The basic concept of social sciences is power in the same sense in which energy is the basic concept of physics" (Russell, 2001). The balance of power between the Russian Federation and the G7 is also the subject of this paper. Polarization (polarity) is one of the main features of the international system. One can distinguish a unipolar system (based on the overwhelming dominance of one state), bipolar (consisting of two equal states with a significant advantage over the others) and multipolar (in which several dominant states have comparable power). Getting to know the estimates of economic, military and geopolitical power should lead to the improvement of countries' security strategies and affect sectors in which a given country shows downward trends or is not developing. When comparing the power of states, it should be considered on the level of generality, using fixed and measurable parameters in a given time unit, a specific space and the people who compose them. A synthetic assessment of the balance of power in quantitative terms shows two categories of power: general and military, and the economic (general) power consists of economic results (gross domestic product), demographic factors (population) and spatial factors (territory area). Military power consists of military-economic factors (military expenditure, which is part of GDP), demographic and military factors (number of active service soldiers) and spatial factors (territory area). Geopolitical power is calculated as the arithmetic mean of the economic (general) power and the double military power (the 
appreciated role of the military factor in shaping the current balance of power). Relations between political units are these between the people who compose them, and take the form of cooperation, struggle and competition.

The obtained data on the above-mentioned factors are divided by the appropriate world values, and enter the obtained fractional values into the formula. After the operation is performed, we will get the power of states as a fraction of the world power.

- $P_{e}=P K B^{0,652} \times L^{0,217} \times a^{0,109}$,

- $P_{w}=W^{0,652} \times S^{0,217} \times a^{0,109}$,

- $P_{g}=\frac{P_{e}+\left(2 \cdot P_{w}\right)}{3}$,

- Markings: $P_{e}-$ economic power (general), $P_{w}$ - military power, $P_{g}-$ geopolitical power, $G D P$ - gross domestic product, $L$ - population, $a$ - territory, $W$ - military expenditure, $S$ - number of soldiers in active service.

It should be emphasized that the world is a competitive environment where there is a constant struggle for limited resources. The activity of states in this regard is based on human action and its systems (praxeology) (Sułek, 2012). It is also determined that competition for power is a zero-sum game. According to Hans Morgenthau, "the signpost that helps political realism find its way in the maze of international politics is the concept of interest defined in terms of power" (Morgenthau, 2010, p. 21).

The indicated model is a priori-deductive. The power exponents used by professor Sułek are related to the golden section of the line ${ }^{5}$. Power in these three dimensions is a stream of energy and means the amount of work done per unit of time (Sułek, 2004; Kiczma, Sułek, 2020). The concept of power is closely related to the concept of international position or status. Each measurement requires the use of specific units of measurement, the paper adopts $1 \mathrm{mir}$ as an expression of the world's power. It follows that the power of individual states is a fraction of this amount. The obtained fractions can be multiplied by any numbers, if we multiply them by 100 , we get the results as a percentage of the power of the world (then the power of the world $=100$ ). In our case, it will be more convenient to multiply them by 1000 (then the world power $=1000$ ), which means that we will express it in milimirs (abbreviation $\mathrm{mM}$ ), i.e. thousandths of the world power. The statistical fundamental of the paper is based on data from the World Bank, the International Monetary Fund (IMF). The data on active duty and military spending in US dollars is derived in part from The Military Balance annuals published by the International Institute for Strategic Studies (IISS) in London and World Bank data. Table 1 shows the GDP of the G7 Group and the Russian Federation.

\footnotetext{
5 "Golden division (Latin sectio aurea), harmonic division, golden proportion, divine proportion (Latin divina proportio) - dividing a segment into two parts so that the ratio of the length of the longer one to the shorter one is the same as that of the entire segment to the longer one. In other words: the length of the longer part is to be the geometric mean of the length of the shorter part and the whole segment". For more see: https://pl.wikipedia.org/wiki/Z\%C5\%82oty_podzia\%C5\%82 \#cite_note-1 (access: 12.11.21); https://encyklopedia.pwn.pl/haslo/;4001815 (access: 12.11.21).
} 
Table 1. GDP of the Russian Federation and the G7 Group at current prices in US dollars (billion)

\begin{tabular}{|c|c|c|c|c|}
\hline Country & $\mathbf{1 9 9 2}$ & $\mathbf{2 0 0 0}$ & $\mathbf{2 0 1 0}$ & $\mathbf{2 0 2 0}$ \\
\hline The USA & $\mathbf{6 . 5 2 0 . 0 0 0}$ & $\mathbf{1 0 . 2 5 2 . 0 0 0}$ & $\mathbf{1 4 . 9 9 2 . 0 0 0}$ & $\mathbf{2 0 . 9 3 7 . 0 0 0}$ \\
\hline in \% of avg the world & 25.65 & 30.42 & 22.66 & 24.75 \\
\hline Great Britain & $\mathbf{1 . 1 8 0 . 0 0 0}$ & $\mathbf{1 . 6 5 8 . 0 0 0}$ & $\mathbf{2 . 4 8 2 . 0 0 0}$ & $\mathbf{2 . 7 0 8 . 0 0 0}$ \\
\hline in \% of avg the world & 4.64 & 4.92 & 3.75 & 3.20 \\
\hline Canada & $\mathbf{0 . 5 7 2 . 0 0 0}$ & $\mathbf{0 . 7 4 4 . 0 0 0}$ & $\mathbf{1 . 6 1 7 . 0 0 0}$ & $\mathbf{1 . 6 4 4 . 0 0 0}$ \\
\hline in \% of avg the world & 2.25 & 2.21 & 2.44 & 1.94 \\
\hline France & $\mathbf{1 . 4 0 1 . 0 0 0}$ & $\mathbf{1 . 4 9 3 . 0 0 0}$ & $\mathbf{2 . 6 4 3 . 0 0 0}$ & $\mathbf{2 . 6 3 0 . 0 0 0}$ \\
\hline in \% of avg the world & 5.51 & 4.43 & 3.99 & 3.11 \\
\hline Germany & $\mathbf{2 . 1 3 2 . 0 0 0}$ & $\mathbf{1 . 9 4 3 . 0 0 0}$ & $\mathbf{3 . 3 9 6 . 0 0 0}$ & $\mathbf{3 . 8 4 6 . 0 0 0}$ \\
\hline in \% of avg the world & 8.39 & 5.76 & 5.13 & 4.55 \\
\hline Italy & $\mathbf{1 . 3 2 0 . 0 0 0}$ & $\mathbf{1 . 1 4 4 . 0 0 0}$ & $\mathbf{2 . 1 3 4 . 0 0 0}$ & $\mathbf{1 . 8 8 6 . 0 0 0}$ \\
\hline in \% of avg the world & 5.19 & 3.39 & 3.23 & 2.23 \\
\hline Japan & $\mathbf{3 . 9 0 9 . 0 0 0}$ & $\mathbf{4 . 9 6 8 . 0 0 0}$ & $\mathbf{5 . 7 5 . 0 0 0}$ & $\mathbf{4 . 9 7 5 . 0 0 0}$ \\
\hline in \% of avg the world & 15.38 & 14.74 & 8.70 & 5.88 \\
\hline Russia & $\mathbf{0 . 4 6 0 . 0 0 0}$ & $\mathbf{0 . 2 5 9 . 0 0 0}$ & $\mathbf{1 . 5 2 5 . 0 0 0}$ & $\mathbf{1 . 4 8 3 . 0 0 0}$ \\
\hline in \% of avg the world & 1.81 & 0.77 & 2.30 & 1.75 \\
\hline world & $\mathbf{2 5 . 4 1 6 . 0 0 0}$ & $\mathbf{3 3 . 7 0 4 . 0 0 0}$ & $\mathbf{6 6 . 1 6 5 . 0 0 0}$ & $\mathbf{8 4 . 5 7 8 . 0 0 0}$ \\
\hline
\end{tabular}

Source: own study based on data from the World Bank and the IMF.

The countries that make up the G7 Group are among the economic powers that developed before the Second World War, and especially after it. Some of them created the European Communities (France, Germany, Italy, Great Britain). Great Britain (due to the industrial revolution and colonial empire) and the USA (industrial revolution, the center of world finance, two world wars won) additionally had great importance in the 19th century, and in the 20th century, the United States gained dominance along with the USSR after 1945 military, especially economic. Japan entered high economic development after 1953, and Canada, despite a small population, has been one of the most developed countries in the world for several decades. All political units from the G7 Group were defined from the second half of the 20th century, as well as in the 21 st century as the West, where societies adhere to a common civilization and a similar culture created thanks to globalization. On the other hand, as a result of the Bolshevik revolution and the defeat of the Third Reich in 1945 , Russia built an empire based mainly on a strong army. The collapse of the USSR in 1991 also led to economic changes, crises and the construction of new opportunities in the field of trade in energy resources, the funds of which are allocated mainly to the development of military potential. The USA dominates the modern world in terms of GDP, its share in the world average ranged from $22 \%$ in 2010 after the perturbations caused by the crisis of 2007-2008 to $30 \%$ in 2000, before the attacks on the World Trade Center and before the wars in Afghanistan and Iraq. In absolute terms, US GDP growth is very visible from 1992 to 2020 and has more than tripled. Other G7 countries also achieved significant GDP gains: Great Britain more than doubled; Canada almost tripled; Germany and France almost doubled. Japan, on the other hand, from a strong global position $-15.38 \%$, fell with 
its GDP to less than $6 \%$ globally in 2020 . The downturn in the economy started as early as 2010 in Japan, when its GDP peaked. Russia's GDP, on the other hand, decreased almost twice as compared to 1992. The following years, however, saw an economic boom, thanks to which the GDP increased 6 times. Currently, the COVID-19 epidemic has reduced GDP in most countries in recent years, but in 2021 there has been an economic rebound in many of them.

Table 2 presents the population relations of the countries under study.

Table 2. Population of the G7 Group and the Russian Federation in millions

\begin{tabular}{|c|c|c|c|c|}
\hline Państwo & $\mathbf{1 9 9 2}$ & $\mathbf{2 0 0 0}$ & $\mathbf{2 0 1 0}$ & $\mathbf{2 0 2 0}$ \\
\hline The USA & $\mathbf{2 5 6 . 5 1 4}$ & $\mathbf{2 8 2 . 1 6 2}$ & $\mathbf{3 0 9 . 3 2 7}$ & $\mathbf{3 2 9 . 4 8 4}$ \\
\hline in \% of avg the world & 4.70 & 4.62 & 4.47 & 4.25 \\
\hline Great Britain & $\mathbf{5 7 . 5 8 0}$ & $\mathbf{5 8 . 8 9 3}$ & $\mathbf{6 2 . 7 7 6}$ & $\mathbf{6 7 . 2 1 5}$ \\
\hline in \% of avg the world & 1.06 & 0.96 & 0.91 & 0.87 \\
\hline Canada & $\mathbf{2 8 . 3 7 1}$ & $\mathbf{3 0 . 6 8 5}$ & $\mathbf{3 4 . 0 0 4}$ & $\mathbf{3 8 . 0 0 5}$ \\
\hline in \% of avg the world & 0.52 & 0.50 & 0.49 & 0.49 \\
\hline France & $\mathbf{5 8 . 8 5 1}$ & $\mathbf{6 0 . 9 1 3}$ & $\mathbf{6 5 . 0 2 8}$ & $\mathbf{6 7 . 3 9 2}$ \\
\hline in \% of avg the world & 1.08 & 1.0 & 0.94 & 0.87 \\
\hline Germany & $\mathbf{8 0 . 6 2 5}$ & $\mathbf{8 2 . 2 1 2}$ & $\mathbf{8 1 . 7 7 7}$ & $\mathbf{8 3 . 2 4 1}$ \\
\hline in \% of avg the world & 1.48 & 1.34 & 1.18 & 1.07 \\
\hline Italy & $\mathbf{5 6 . 7 9 7}$ & $\mathbf{5 6 . 9 4 2}$ & $\mathbf{5 9 . 2 7 7}$ & $\mathbf{5 9 . 5 5 4}$ \\
\hline in \% of avg the world & 1.04 & 0.93 & 0.86 & 0.77 \\
\hline Japan & $\mathbf{1 2 4 . 4 2 5}$ & $\mathbf{1 2 6 . 8 4 3}$ & $\mathbf{1 2 8 . 0 7 0}$ & $\mathbf{1 2 5 . 8 3 6}$ \\
\hline in \% of avg the world & 2.28 & 2.07 & 1.85 & 1.62 \\
\hline Russia & $\mathbf{1 4 8 . 3 8 0}$ & $\mathbf{1 4 6 . 5 9 7}$ & $\mathbf{1 4 2 . 8 4 9}$ & $\mathbf{1 4 4 . 1 0 4}$ \\
\hline in \% of avg the world & 2.72 & 2.40 & 2.06 & 1.86 \\
\hline world & $\mathbf{5 . 4 5 3 . 0 0 0}$ & $\mathbf{6 . 1 1 4 . 0 0 0}$ & $\mathbf{6 . 9 2 2 . 0 0 0}$ & $\mathbf{7 . 7 5 3 . 0 0 0}$ \\
\hline
\end{tabular}

Source: own study based on data from the World Bank.

All G7 countries and Russia recorded a decline in the demographic position in percent worldwide. This is due to the aging of these societies and the large population growth in Asia, Africa and South America. These declines have been in effect since 1992 and are still ongoing. During this time, over two billion people came to the world in 30 years. In the analyzed years, only the USA increased its demographic position in absolute numbers from 256 million to 329 million. During these thirty years the societies of Great Britain, Canada, France, Germany and Italy grew by several million. These increases were mainly due to the arrival of emigrants. The number of Japanese people fluctuates around 124-125 million with a marked downward trend. Russia, on the other hand, is depopulating the most in relation to other countries, it has lost over 4 million in the years indicated in Table 2.

Table 3 shows the area of countries, which also influenced the power of countries for centuries. 
Table 3. Area of countries in thous. $\mathrm{km}^{2}$

\begin{tabular}{|c|c|}
\hline Country & area \\
\hline The USA & $\mathbf{9 8 3 3 5 1 7}$ \\
\hline in \% of avg the world & 7.22 \\
\hline Great Britain & $\mathbf{2 4 2 ~ 4 9 5}$ \\
\hline in \% of avg the world & 0.18 \\
\hline Canada & $\mathbf{9 9 8 4 ~ 6 7 0}$ \\
\hline in \% of avg the world & 7.33 \\
\hline France & $\mathbf{5 5 1 5 0 0}$ \\
\hline in \% of avg the world & 0.41 \\
\hline Germany & $\mathbf{3 5 7 3 7 6}$ \\
\hline in \% of avg the world & 0.26 \\
\hline Italy & $\mathbf{3 0 2 ~ 0 7 3}$ \\
\hline in \% of avg the world & 0.22 \\
\hline Japan & $\mathbf{3 7 7 9 3 0}$ \\
\hline in \% of avg the world & 0.28 \\
\hline Russia & $\mathbf{1 7 0 9 8 ~ 2 4 6}$ \\
\hline in \% of avg the world & 12.56 \\
\hline world & $\mathbf{1 3 6 1 6 2 ~ 0 0 0}$ \\
\hline
\end{tabular}

Source: own study based on UN data

Among the countries presented, the largest areas are Russia, Canada and the USA. The remaining countries have a much smaller area. The territory, however, no longer plays a similar geopolitical role in the modern world as it did in the nineteenth century or in the period until the end of World War II.

Table 4 contains data on military spending in billion US dollars.

World military spending increased 2.5 times from 1992 to 2020. The main world powers, wishing to maintain their position in the international balance of power, spent ever greater sums for this purpose. Between 1992 and 2020, the US more than doubled its defense spending from $\$ 325$ billion to $\$ 778$ billion. Also among the other G7 countries, increases in this expenditure in the years indicated in the table or small decreases are visible mainly due to the COVID-19 pandemic in recent years (Great Britain, Italy, Japan). Other countries such as Canada, France and Germany spent a little more on military in 2020 than in 2010 (SIPRI Military Expenditure Database, 2021). Russia (USSR) recorded a decline in defense spending until the end of the 20th century, which was mainly due to the collapse of the USSR. After 2000, however, there was a visible increase in these investments to the level of USD 61 billion in 2021. In relation to the USA, Russia's defense budget was 8 times smaller in 1992, 35 times smaller in 2000, and 12 times smaller in 2010 and 2020. In the percentage of the world average, the G7 countries have fallen in the last 30 years, at the expense of China and India in particular, but it must be remembered that the US spent over $40 \%$ of global defense spending in those years. Russia, despite having a large military arsenal on a global scale, spent more than $5 \%$ on the military in 1992 , and $3 \%$ in 2020 . 
Table 4. Military expenditure of the G7 Group and the Russian Federation in US billion dollars

\begin{tabular}{|c|c|c|c|c|}
\hline Państwo & $\mathbf{1 9 9 2}$ & $\mathbf{2 0 0 0}$ & $\mathbf{2 0 1 0}$ & $\mathbf{2 0 2 0}$ \\
\hline The USA & $\mathbf{3 2 5 . 0 3 4}$ & $\mathbf{3 2 0 . 0 8 6}$ & $\mathbf{7 3 8 . 0 0 5}$ & $\mathbf{7 7 8 . 2 3 2}$ \\
\hline in \% of avg the world & 44.51 & 43.12 & 44.78 & 40.34 \\
\hline Great Britain & $\mathbf{4 5 . 5 9 3}$ & $\mathbf{3 9 . 3 4 4}$ & $\mathbf{6 3 . 9 7 9}$ & $\mathbf{5 9 . 2 3 8}$ \\
\hline in \% of avg the world & 6.24 & 5.30 & 3.88 & 3.07 \\
\hline Canada & $\mathbf{1 0 . 7 8 9}$ & $\mathbf{8 . 2 9 9}$ & $\mathbf{1 9 . 3 1 6}$ & $\mathbf{2 2 . 7 5 5}$ \\
\hline in \% of avg the world & 1.48 & 1.12 & 1.17 & 1.18 \\
\hline France & $\mathbf{3 7 . 9 0 2}$ & $\mathbf{2 8 . 4 0 3}$ & $\mathbf{5 2 . 0 4 4}$ & $\mathbf{5 2 . 7 4 7}$ \\
\hline in \% of avg the world & 5.19 & 3.83 & 3.16 & 2.73 \\
\hline Germany & $\mathbf{3 9 . 5 0 2}$ & $\mathbf{2 6 . 4 9 8}$ & $\mathbf{4 3 . 0 2 6}$ & $\mathbf{5 2 . 7 6 5}$ \\
\hline in \% of avg the world & 5.41 & 3.57 & 2.61 & 2.74 \\
\hline Italy & $\mathbf{2 2 . 1 7 7}$ & $\mathbf{1 9 . 8 7 9}$ & $\mathbf{3 2 . 0 2 1}$ & $\mathbf{2 8 . 9 2 1}$ \\
\hline in \% of avg the world & 3.04 & 2.68 & 1.94 & 1.50 \\
\hline Japan & $\mathbf{3 5 . 9 9 9}$ & $\mathbf{4 5 . 5 1 0}$ & $\mathbf{5 4 . 6 5 5}$ & $\mathbf{4 9 . 1 4 9}$ \\
\hline in \% of avg the world & 4.93 & 6.13 & 3.32 & 2.55 \\
\hline Russia & $\mathbf{3 9 . 6 8 0}$ & $\mathbf{9 . 2 2 8}$ & $\mathbf{5 8 . 7 2 0}$ & $\mathbf{6 1 . 7 1 3}$ \\
\hline in \% of avg the world & 5.43 & 1.24 & 3.56 & 3.20 \\
\hline world & $\mathbf{7 3 0 . 2 9 9}$ & $\mathbf{7 4 2 . 3 3 3}$ & $\mathbf{1 . 6 4 8 . 0 0 0}$ & $\mathbf{1 . 9 2 9 . 0 0 0}$ \\
\hline
\end{tabular}

Source: own study based on data from the World Bank and Military Balance.

The size of the armed forces also plays an important role in strengthening the military potential of states. Table 5 contains information on the number of active soldiers in active service without paramilitary forces of the G7 Group and the Russian Federation.

The US military potential is manifested not only by the number of military expenditure, but also by the number of active soldiers. Although the percentage of US troops is declining worldwide: from $7.83 \%$ in 1992 to $5 \%$ in 2020 , in absolute numbers it is still very large and exceeds or oscillates around 1.5 million soldiers. Other G7 countries have also declined in percentages of the world average over the past 30 years. All of them also cut military positions and focused on building a smaller but fully professional army. Also subsequent crises: started in 2007 and the last one associated with the pandemic, led to a reduction in the number of jobs in the army, and therefore also budget expenditure on them. The remaining G7 countries, for instance in 2020, had a total of 1,013,000 soldiers, which constituted $73 \%$ of the number of soldiers in the American army. In addition to Japan, other countries are US allies in NATO, and the government in Tokyo supports many US interventions in the world outside of this organization. On the other hand, the Russian Federation inherited a large number of soldiers from the USSR, in 1992 there were almost 2 million, not including paramilitary forces, which could be quickly used to support or replace the regular armed forces. In the following years, however, the size of the army in terms of soldiers was reduced, but in 2020 the state still had 900,000 of them. However, as a percentage of the world scale, it is only 3.23\% (Military Balance, 2020). 
Table 5. The number of soldiers in active service of the G7 Group and the Russian Federation in thousands

\begin{tabular}{|c|c|c|c|c|}
\hline Country & $\mathbf{1 9 9 2}$ & $\mathbf{2 0 0 0}$ & $\mathbf{2 0 1 0}$ & $\mathbf{2 0 2 0}$ \\
\hline The USA & $\mathbf{1 . 9 2 0}$ & $\mathbf{1 . 4 5 5}$ & $\mathbf{1 . 5 6 9}$ & $\mathbf{1 . 3 8 0}$ \\
\hline in \% of avg the world & 7.83 & 4.96 & 5.58 & 4.99 \\
\hline Great Britain & $\mathbf{2 9 3}$ & $\mathbf{2 1 3}$ & $\mathbf{1 7 4}$ & $\mathbf{1 4 8}$ \\
\hline in \% of avg the world & 1.19 & 0.73 & 0.62 & 0.54 \\
\hline Canada & $\mathbf{8 2}$ & $\mathbf{6 8}$ & $\mathbf{6 5}$ & $\mathbf{6 7}$ \\
\hline in \% of avg the world & 0.33 & 0.23 & 0.23 & 0.24 \\
\hline France & $\mathbf{5 2 2}$ & $\mathbf{3 8 9}$ & $\mathbf{3 4 2}$ & $\mathbf{2 0 4}$ \\
\hline in \% of avg the world & 2.13 & 1.33 & 1.22 & 0.74 \\
\hline Germany & $\mathbf{4 4 2}$ & $\mathbf{2 2 1}$ & $\mathbf{2 5 1}$ & $\mathbf{1 8 1}$ \\
\hline in \% of avg the world & 1.80 & 0.75 & 0.89 & 0.65 \\
\hline Italy & $\mathbf{4 7 1}$ & $\mathbf{5 0 3}$ & $\mathbf{3 5 9}$ & $\mathbf{1 6 6}$ \\
\hline in \% of avg the world & 1.92 & 1.71 & 1.28 & 0.60 \\
\hline Japan & $\mathbf{2 4 2}$ & $\mathbf{2 4 9}$ & $\mathbf{2 6 0}$ & $\mathbf{2 4 7}$ \\
\hline in \% of avg the world & 0.99 & 0.85 & 0.92 & 0.89 \\
\hline Russia & $\mathbf{1 . 9 0 0}$ & $\mathbf{1 . 4 2 7}$ & $\mathbf{1 . 4 3 0}$ & $\mathbf{9 0 0}$ \\
\hline in \% of avg the world & 7.74 & 4.86 & 5.08 & 3.23 \\
\hline world & $\mathbf{2 4 . 5 3 3}$ & $\mathbf{2 9 . 3 5 3}$ & $\mathbf{2 8 . 1 3 3}$ & $\mathbf{2 7 . 6 4 2}$ \\
\hline
\end{tabular}

Source: own study based on data from the World Bank and Military Balance.

Table 6 presents the general (economic) power of the analyzed countries in the years 1992-2020.

Table 6. The economic (general) power of the G7 Group and the Russian Federation in mM, i.e. the world $=1000$

\begin{tabular}{|c|c|c|c|c|}
\hline Country & $\mathbf{1 9 9 2}$ & $\mathbf{2 0 0 0}$ & $\mathbf{2 0 1 0}$ & $\mathbf{2 0 2 0}$ \\
\hline The USA & 159.32 & 177.30 & 145.31 & 152.26 \\
\hline Great Britain & 25.25 & 25.70 & 21.26 & 18.98 \\
\hline Canada & 20.25 & 19.84 & 21.10 & 18.17 \\
\hline France & 31.03 & 26.44 & 24.41 & 20.38 \\
\hline Germany & 41.67 & 31.96 & 28.81 & 26.08 \\
\hline Italy & 27.74 & 20.51 & 19.48 & 14.96 \\
\hline Japan & 68.39 & 65.16 & 45.08 & 33.94 \\
\hline Russia & 26.68 & 14.85 & 29.41 & 24.06 \\
\hline world & 1000 & 1000 & 1000 & 1000 \\
\hline
\end{tabular}

Source: own study.

General power is a product of the balance of forces that arose over a long period of historical development. The calculations of the general power based on Sułek's model presented in Table 6 indicate the sustained advantage of the USA over the other countries included in the power study between 1992 and 2020. After 2000, as a result of foreign interventions and the economic crisis (Drezner, 2019), the USA began to lose its position 
mainly to China (Todd, 2003). As geopoliticians indicate, after 2010, the bipolar system began to emerge again, but in a new configuration: the USA - China, and not the USA USSR (Russia), as in the past. Between 2000 and 2020, the US general power decreased by $25 \mathrm{mM}$, which is $7.06 \mathrm{mM}$ lower than in 1992. The percentage of the US power also decreased by $14 \%$ between 2000 and 2020 . Between 2000 and 2010, this change was even higher, amounting to $18 \%$. Among the other G7 countries, there were declines in general power indicators between 1992 and 2020. The downward trend is visible when it comes to the power of Great Britain, Canada, France, Germany, Italy and Japan. The biggest decrease was recorded by Japan (by $34 \mathrm{mM}$ and as much as 50\%) and Italy (by $13 \mathrm{mM}$ and $46 \%$ ) between the power in 1992 and 2020. These declines, especially in Japan's position, can be described as spectacular. The general power of Russia fluctuated in the analyzed years between $1.5 \%$ in 2000 and $2.9 \%$ in 2010 in the world scale. In relation to the USA, the general power of Russia in 2020 was 6 times smaller, and in 2000 even 12 times smaller.

Table 7 shows the military power of the G7 and the Russian Federation between 1992 and 2020 .

Table 7. Military power of the G7 Group and the Russian Federation in mM, i.e. the world $=1000$

\begin{tabular}{|c|c|c|c|c|}
\hline Country & $\mathbf{1 9 9 2}$ & $\mathbf{2 0 0 0}$ & $\mathbf{2 0 1 0}$ & $\mathbf{2 0 2 0}$ \\
\hline The USA & 254.84 & 226.08 & 237.73 & 216.81 \\
\hline Great Britain & 31.45 & 25.37 & 20.00 & 16.64 \\
\hline Canada & 13.98 & 10.77 & 11.10 & 11.26 \\
\hline France & 34.57 & 25.57 & 22.14 & 18.09 \\
\hline Germany & 32.67 & 20.62 & 17.44 & 16.82 \\
\hline Italy & 22.32 & 20.06 & 15.27 & 10.95 \\
\hline Japan & 27.15 & 30.29 & 20.67 & 17.28 \\
\hline Russia & 68.54 & 23.68 & 47.51 & 40.21 \\
\hline world & 1000 & 1000 & 1000 & 1000 \\
\hline
\end{tabular}

Source: own study.

Table 7 shows that the largest and so far indisputable military power among the abovementioned countries is the USA - between 216 and $254 \mathrm{mM}$ per $1000 \mathrm{mM}$ (the whole world). The percentage share of the US in the world's military power ranged from $21.6 \%$ to $25.5 \%$ between 1992 and 2020 . The downward trend of this country is also visible in the table (loss of $38 \mathrm{mM}$ and $15 \%$ of its power). The other $\mathrm{G} 7$ countries remain in a downward trend in terms of military power. Russia inherited a fairly significant position in this hierarchy from the USSR in 1992, i.e. $6.8 \%$ of the world's power. However, in the following years there were declines in this respect. In 2020, Russia's share amounted to $4 \%$ of the world's military power and was more than 5 times smaller than the US share. It follows that we are dealing with a unipolar system in which, according to geopoliticians, the USA still has a significant advantage over China in this respect, as well as over Russia, and even more so over other members of the G7 Group.

Table 8 contains references to the geopolitical power of the surveyed countries, its results are based on Tables 6 and 7 . 
Table 8. The geopolitical power of the G7 Group and the Russian Federation in mM, i.e. the world $=1000$

\begin{tabular}{|c|c|c|c|c|}
\hline Country & $\mathbf{1 9 9 2}$ & $\mathbf{2 0 0 0}$ & $\mathbf{2 0 1 0}$ & $\mathbf{2 0 2 0}$ \\
\hline The USA & 223.00 & 209.82 & 206.92 & 195.30 \\
\hline Great Britain & 29.38 & 25.48 & 20.42 & 17.42 \\
\hline Canada & 16.07 & 13.79 & 14.43 & 13.56 \\
\hline France & 33.39 & 25.86 & 22.90 & 18.85 \\
\hline Germany & 35.67 & 24.40 & 21.23 & 19.90 \\
\hline Italy & 24.13 & 20.21 & 16.67 & 12.26 \\
\hline Japan & 40.89 & 41.91 & 28.81 & 22.83 \\
\hline Russia & 54.59 & 20.74 & 41.48 & 34.82 \\
\hline world & 1000 & 1000 & 1000 & 1000 \\
\hline
\end{tabular}

Source: own study.

The geopolitical power created on the basis of the resultant of general and military power is the third expression of state power. It includes economic and military aspects. Therefore, the military factor has a special share in its construction twice. According to researchers, recent years have led to the formation of a bipolar system with the US advantage over China (Zeng, Breslin, 2016). Among all the countries surveyed, a downward trend in geopolitical power between 1992 and 2020 is dominant. The US lost $28 \mathrm{mM}$ of its power during this time, down $13 \%$. Italy $-50 \%$, Germany $-45 \%$, Japan $-44 \%$ and France $-42 \%$ of the geopolitical power in 30 years - experienced the biggest drops in percentages. Russia also recorded declines in this power over the period indicated, while also undergoing fluctuations. It reached the greatest geopolitical power in $1992-55 \mathrm{mM}$, the lowest in 2000 $-21 \mathrm{mM}$, and in 2020 its index was $35 \mathrm{mM}$ (1000 all over the world), which was 5.5 times lower than the USA.

\section{CONCLUSIONS}

The G7 countries and Russia are still among the most important and strongest countries of our globe, along with China, India and Brazil. They actively pursue their foreign policies, striving to gain even greater potential in a resource-limited world. It is connected with the achievement of greater importance in the international arena. The presented dimensions of the general, military and geopolitical power of the G7 Group and Russia allow drawing the following conclusions:

1. The main goal of the G7 Group is to maintain its position in the world and participate in influencing the most important decisions taken in contemporary international relations.

2. These countries must compete more effectively for power with Russia, China, India and Brazil, which want to violate the international status quo and have a greater influence, for example, on the international financial system.

3. The position of the United States appears to be unwavering in the three types of powers studied, but despite its significant advantage over other countries, the country's power values are in a downward trend.

4. It will become increasingly difficult for the G7 to play a leading role in the world. 
5. With the exception of the USA, the remaining G7 countries decreased their position in terms of power in $1992-2020$ by as much as $40-50 \%$. In the period after World War II, these countries dominated the world economically, and thanks to the alliance with the USA also militarily and politically.

6. In the modern world, the G7 countries are struggling with increasing economic (inflation, economic crises, lowering GDP, high taxes, expensive life) and demographic problems (aging populations).

7. The G7 countries (especially the USA) had (Japan, Italy, Germany, France) in 1992 and now (Japan, Germany) have an overall (economic) power advantage over Russia.

8. In the field of military power, there is a huge advantage of the USA in the world over the countries surveyed in the paper. All other countries, as well as Russia, are in a downward trend in this respect. The level of their military power since 1992 has declined quite significantly over the 30 years to 2020 on a global scale.

9. In terms of geopolitical power, the USA has an unquestionable position among the analyzed countries, but since 1992 they have also been in a downward trend (as well as all other G7 countries, including Russia) in favor of developing Asian and African countries, which as part of a zero-sum game of struggle for power, while developing, take over power from other countries.

10. Russia reached the lowest values of general, military and geopolitical power at the turn of the millennium in 2000. On the other hand, the highest US figures for general power were achieved in 2000, military and geopolitical in 1992.

11. Russia has dropped out of the bipolar system, and China will take its place next to the US, which will have a significant advantage in this configuration, especially when it comes to military power.

The increasing success of underdeveloped countries in the world in recent decades has resulted in a growth in their position on the international arena. Due to the fact that the struggle for power is a zero-sum game, it weakens the position of Western countries, i.e. the G7 Group in particular. Analysts predict that the decline in US power will be halted. On the other hand, Fareed Zakaria stated that US domination under the new international order after the epidemic was no longer possible (Zakaria, 2020). China, on the other hand, may fall into a development trap similar to that which Japan is currently in. In relation to Russia, analysts believe that its power will decline. However, it should be remembered that Russia is strengthening its global position through participation in the UN Security Council, military power (including the possession of nuclear weapons) and a raw material and energy power.

The indicated synthetic measures of power may be helpful in developing an international/national security assessment. It also influences the design of state security strategies (Strachan, 2019).

\section{REFERENCES}

Aron, R. (1995). Pokój i wojna między narodami (teoria). Warszawa.

Batchelor, T. (2017). Russia announces plan to permanently leave G8 group of industrialised nations after suspension for Crimea annexation. "Independent", 13 January.

Drezner, D. W. (2019). Counter-Hegemonic Strategies in the Global Economy. "Security Studies", 28(3). 
Kiczma, Ł., Sułek, M. (2020). Potęga państw 2020. Rankingi potęgometryczne. Warszawa.

Larsdotter, K. (2019). Military strategy in the 21st century. "Journal of Strategic Studies", 42(2).

Matera, R. (2006). Geneza G-7. Kontekst gospodarczy i polityczny. „, Studia Polityczne”, No. 18.

Morgenthau, H., Polityka między narodami. Walka o potęgę i pokój, Warszawa 2010.

Rotfeld, A. D. (1990). Europejski system bezpieczeństwa in statu nascendi. Warszawa: PISM.

Russell, B. (2001). Władza. Nowa analiza społeczna. Warszawa.

Scazzieri, L. (2017). Europe, Russia and the Ukraine crisis: the dynamics of coercion. "Journal of Strategic Studies", 40(3).

SIPRI Military Expediture Database. Data for all countries 1988-2020 (excel spreadsheet) [access: 6.12.2021]. Access on the internet: https://www.sipri.org/databases/milex

Strachan, H. (2019). Strategy in theory; strategy in practice. "Journal of Strategic Studies", 42(2).

Sułek, M. (2004). Badania i pomiar potegi państw po Zimnej Wojnie-metody i wyniki, ,,Zeszyty Naukowe AON", No. 1(54).

— (2012). Prakseologiczna teoria stosunków międzynarodowych. „Przegląd Strategiczny”, No. 1.

- (2013). Potęga państw. Modele i zastosowania. Warszawa: Wydawnictwo Rambler. (2014). USA, UE i Chiny - trzy bieguny w globalnym układzie sit. „, Rocznik Strategiczny”, 2013/14.

The Military Balance 2020 (2020). International Institute for Strategic Studies-Routledge. London.

Tood, E. (2003). Schytek imperium. Rozważania o rozkładzie systemu amerykańskiego. Warszawa: Wyd. Dialog.

Zakaria, F. (2020). Ten Lessons for a Post-Pandemic World. New York.

Zeng, J., Breslin, S. (2016). China's 'new type of Great Power relations': a G2 with Chinese characteristics?. "International Affairs”, Vol. 92, Issue 4, July.

DOI: $10.7862 /$ rz.2021.hss.37

The text was submitted to the editorial office: December 2021.

The text was accepted for publication: December 2021. 
